\title{
Texas Tech University Students Take On Zimbabwe
}

\author{
Kaitlin Danis, Ashley Hogan, and Kirsten Smith
}

Texas Tech University, Lubbock, Texas 79409 (kaitlin.danis@ttu.edu)

$\mathrm{O}_{1}^{n}$ the night of Wednesday, 14 May 2014, 27 Texas Tech students tossed and turned in their beds, desperate for sleep, imagining what the next three weeks would bring. Most of us had spent months preparing for the trip by learning about the country, raising money, and filling out travel paperwork. Forget studying for finals, we were more concerned with packing! Leaving something behind was simply not an option, but getting everything to fit into a single suitcase was certainly a challenge. Herpetology was not the focus for this trip, but we were excited about all the wildlife we were going to see. We prepared ourselves with a series of field guides. Although one frog guide specific to Zimbabwe (Lambiris 1989) was too technical for our purposes, we generally found the South African snake (Marais 2004) and frog guides (du Preez and Carruthers 2009), which have individual records and maps for all species, more useful than the "reptile" guide for lizards, turtles, and crocodilians (Alexander and Marais 2007). Consequently, we were unable in many instances to identify the reptiles we encountered to species.

After considerable preparation, we finally were ready to embark on one of the greatest adventures of our lives. After three airports, one lengthy layover, and roughly two days of travel, we were excited to be on solid ground again — and our three-week journey across South Africa and Zimbabwe began (Fig. 1). As we waited in the South African customs line, most of us tried to get on our phones to connect with friends and family, but to no avail. We certainly weren't in Texas anymore.

\section{South Africa: Kenjara Lodge \\ (http://www.kenjara.co.za/)}

A brief car trip from the Johannesburg airport delivered us to the Kenjara Lodge in the Gauteng Province of South Africa. Along the way, we couldn't help but notice similarities between the climate of South Africa and Lubbock, Texas. The highly anticipated acacia trees and wild animals were nowhere to be found. Instead, the land was scattered with impoverished neighborhoods, eucalyptus trees, and tall-grass prairie.

Our first stop was the Cradle of Humankind World Heritage Site in Maropeng, where we learned about our human ancestors and the evolution of other species (Fig. 2). We also explored the Sterkfontein caves, where we viewed current archaeological dig sites and the site where "Mrs. Ples" (Australopithecus africanus) was found. The view surrounding the caves still might be very close to what some of our earliest ancestors experienced when they roamed the area (Fig. 3).

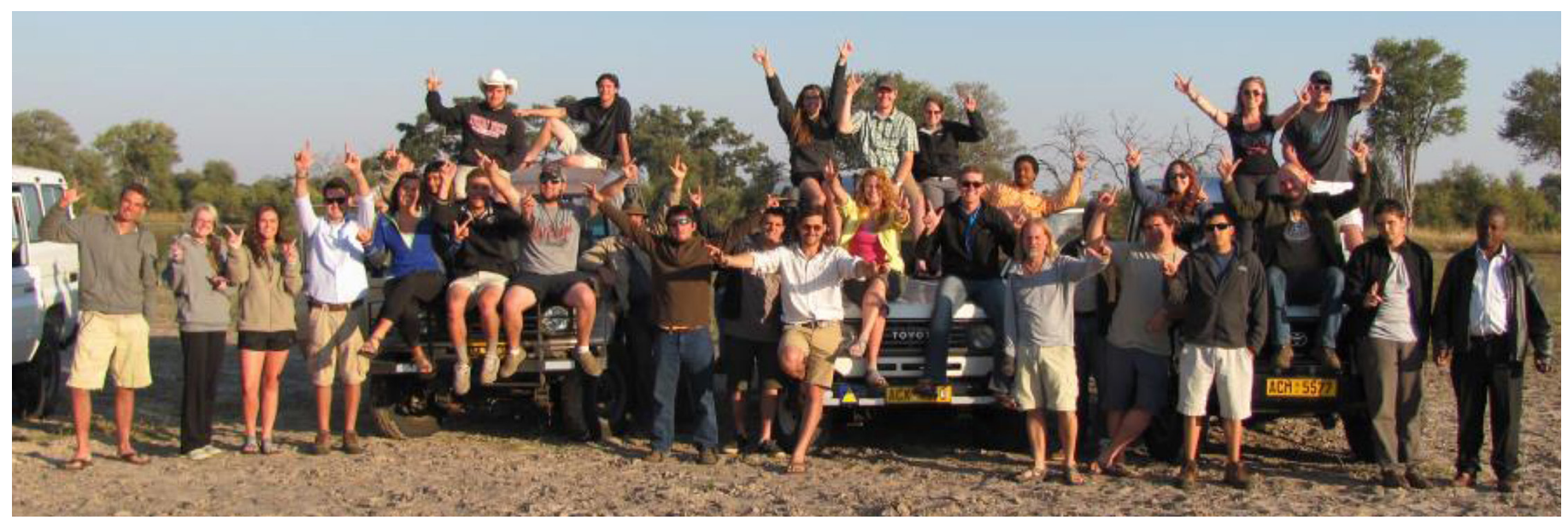

Fig. 1. The entire group at Hwange National Park, Zimbabwe. Four-wheel drive vehicles are essential for visiting many places in Africa. Photograph by Gad Perry. 


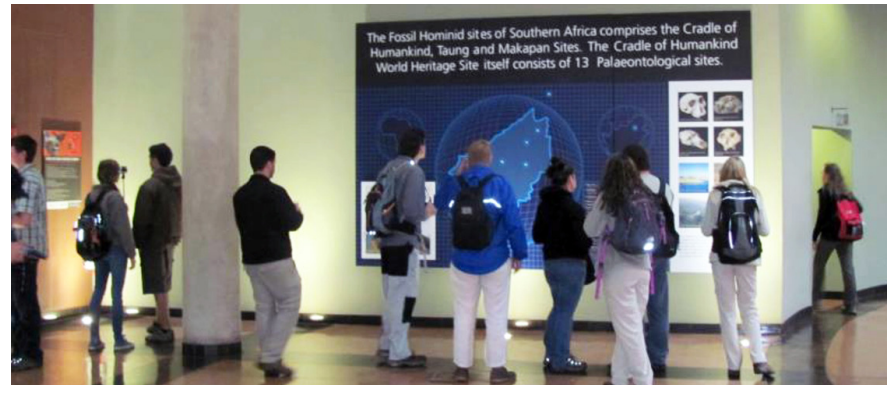

Fig. 2. The entrance to the Cradle of Humankind Museum at Maropeng. The many interactive displays include a boat ride that takes visitors back in time. Photograph by Gad Perry.

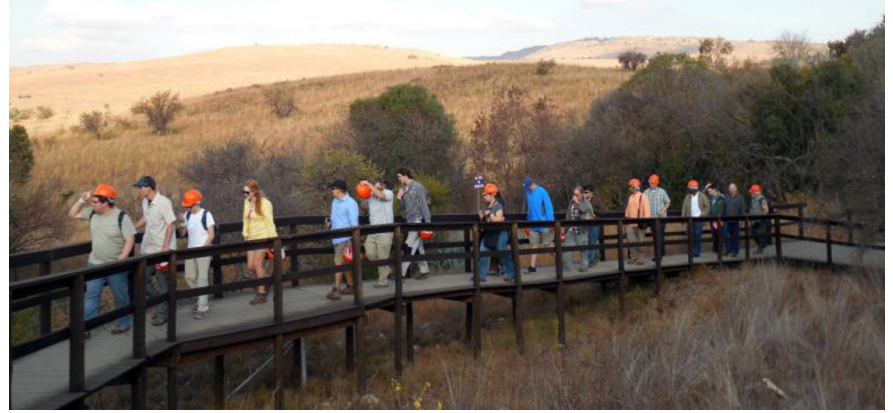

Fig. 3. Coming out of the Sterkfontein caves at Maropeng. Photograph by Kaitlin Danis.

Our trip was during the North American summer, which meant it was winter in South Africa. We had hoped to see some chameleons (eight genera and over 160 species are known from Africa; Alexander and Marais 2007); they are common in the region and very different from the lizards with which we are familiar. Although we were told about them wherever we went and saw images of chameleons in local art (Fig. 4), we saw not one individual during this trip.

We departed Kenjara Lodge early the next day and spent a memorable eight hours first passing through South African customs in order to leave the country and then waiting in another long line until we were finally granted permission to enter Zimbabwe (we suggest taking a plane into Bulawayo for a much faster and smoother entry). After our exhausting day at the border, an additional drive took us to Limpopo. The delicious dinner served by the Nottingham Fishing Retreat staff and a night spent admiring the stars were the perfect ending to our fifteen-hours of traveling.

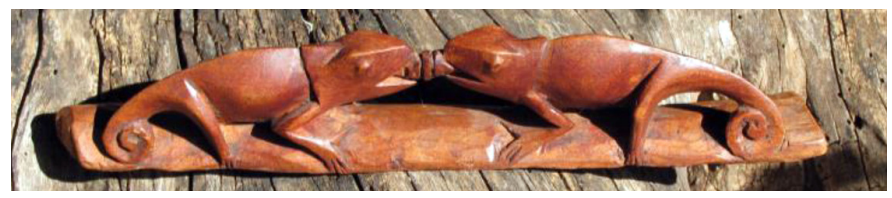

Fig. 4. The only chameleons we saw during the trip... Artwork by Mr. Johnson, Ngamo Village near Hwange. Photograph by Gad Perry.
Limpopo, Zimbabwe: The Nottingham Fishing Retreat (http://nottinghamadventures.co.za/)

The Nottingham Fishing Retreat sits on the Limpopo River, the border between South Africa and Zimbabwe. Our first morning at the lodge afforded us the opportunity to view the large dam in front of the comfortable cottages. The dam is a valuable asset to the lodge for fishing and recreation. It supports agriculture and holds a diverse man-made aquatic ecosystem. We spent one afternoon with our guides taking a tour of the river, where we had the opportunity to view Nile Crocodiles (Crocodylus niloticus) up close. Many crocodiles spend the days basking in the sun, often with gaping mouths (Fig. 5). Crocodiles do most of their hunting at night, relying on the warm water to keep their body temperatures from dropping too low. This is one of the largest and most dangerous species of crocodile, and a warning by the lake reminds guests to be careful (Fig. 6). National Geographic Magazine (2015) reported that Nile Crocodiles kill up to 200 people annually, so we made sure to heed the warnings. We were told that fish poachers have disappeared in these waters, presumably prey to some of the larger crocs. We also observed

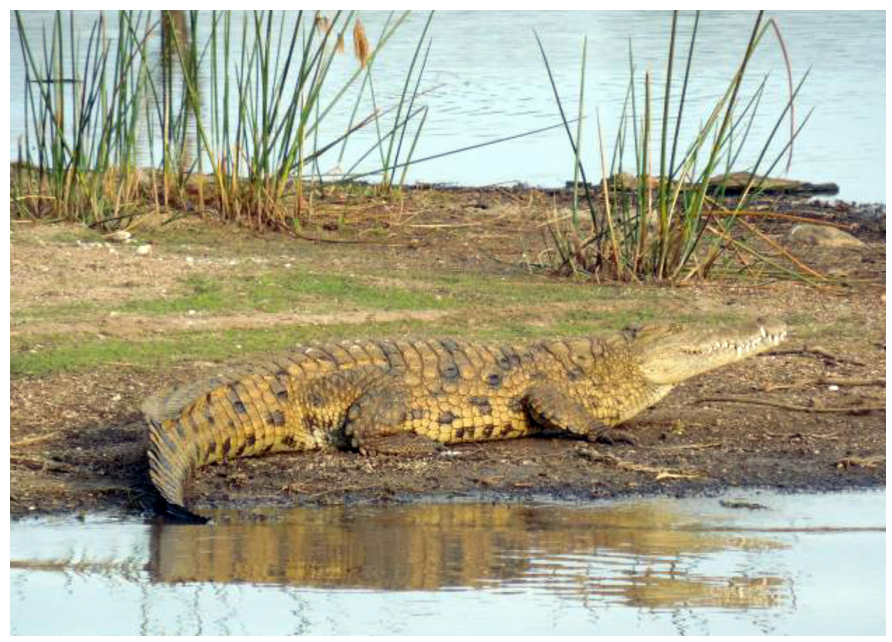

Fig. 5. One of the Nile Crocodiles (Crocodylus niloticus) seen sunning itself by the lake at the Nottingham Fishing Retreat by the Limpopo River. Photograph by Kaitlin Danis.

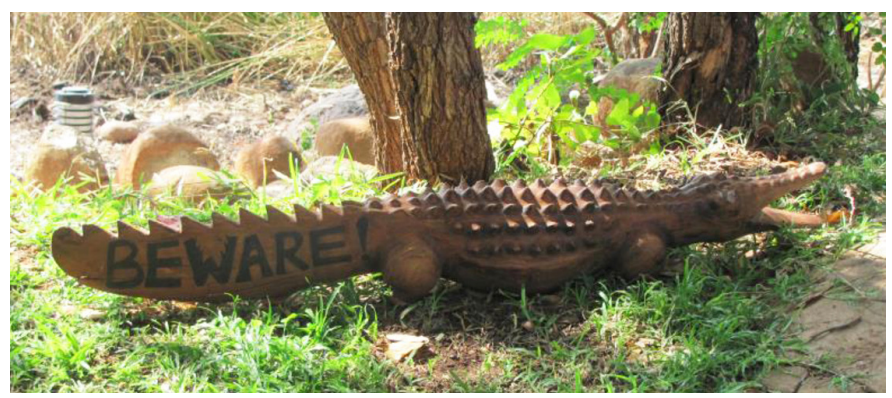

Fig. 6. This wooden crocodile, placed near the boathouse at the Nottingham Fishing Retreat, reminds guests that the innocent-seeming lake water can be deadly. Photograph by Gad Perry. 
Nile Monitor Lizards (Varanus niloticus, Fig. 7), several terrapins (Pelusios sp.; Fig. 8), and African Fish Eagles (Haliaeetus vocifer, Fig. 9).

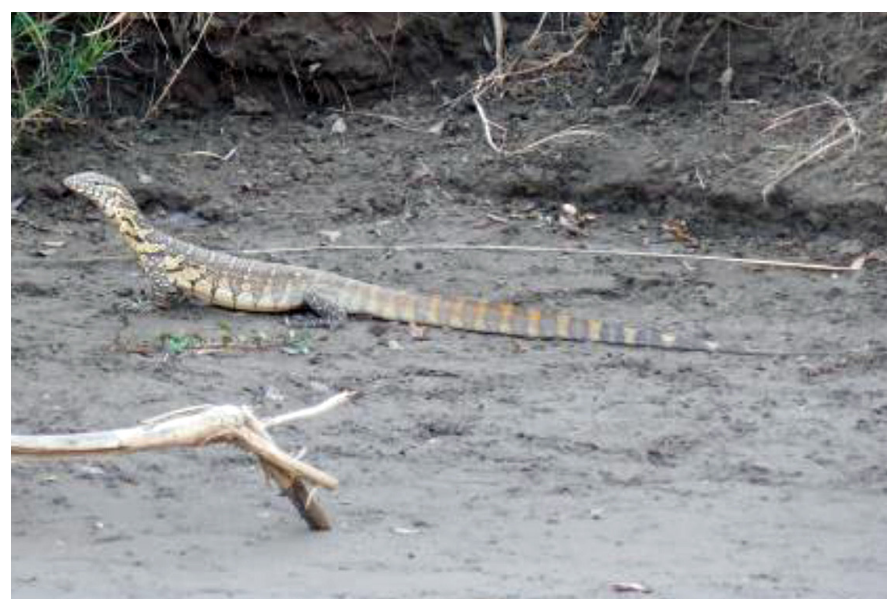

Fig. 7. A juvenile Nile Monitor (Varanus niloticus) at lake's edge. We saw a number of these large lizards, ranging from juveniles to full-sized adults, during our two-hour boat ride. Photograph by Kaitlin Danis.

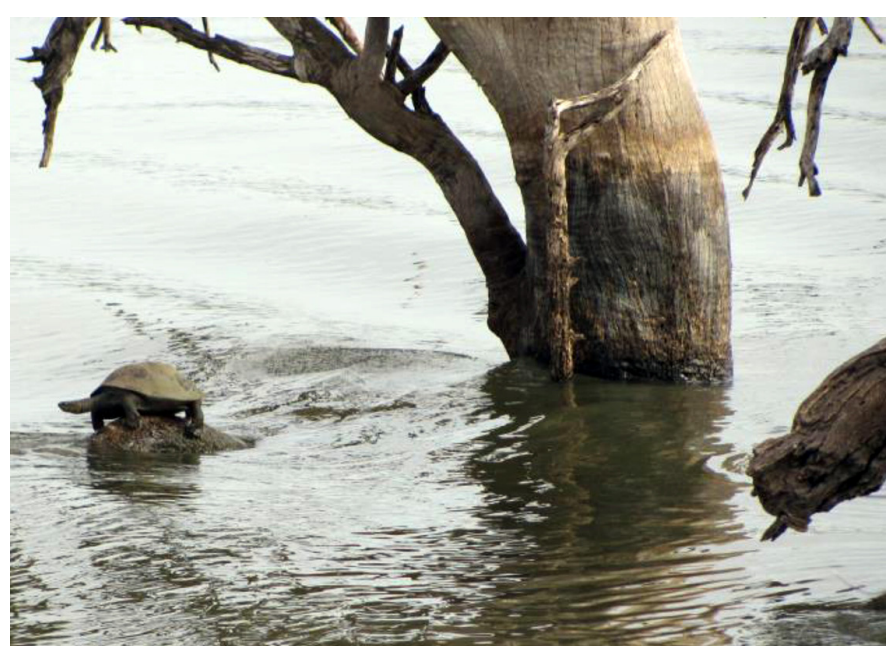

Fig. 8. Africa is home to several species of side-necked terrapins. This adult was sunning itself on a dead tree left from before the lake was created. Photograph by Gad Perry.

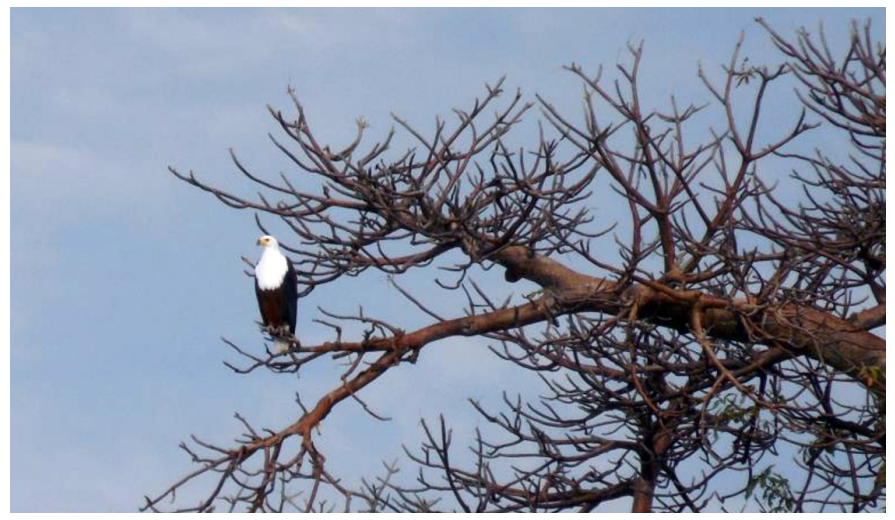

Fig. 9. An African Fish Eagle (Haliaeetus vocifer) looks for food on the lake. Photograph by Kaitlin Danis.
Our later days in Limpopo were spent visiting Fly Camp, a viewing spot above a baited feeding area where African Elephants (Loxodonta africana; Fig. 10) and other animals feed on excess agricultural production. In addition to the up-

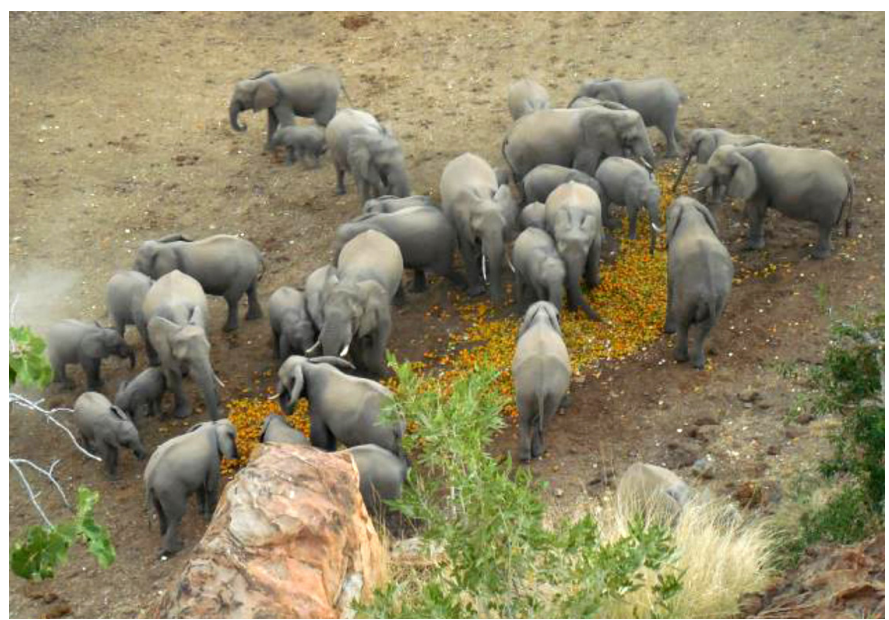

Fig. 10. African Elephants (Loxodonta africana) eating orange pulp at Fly Camp. Large numbers of elephants troop in every day to enjoy leftover agricultural produce. Photograph by Kaitlin Danis.

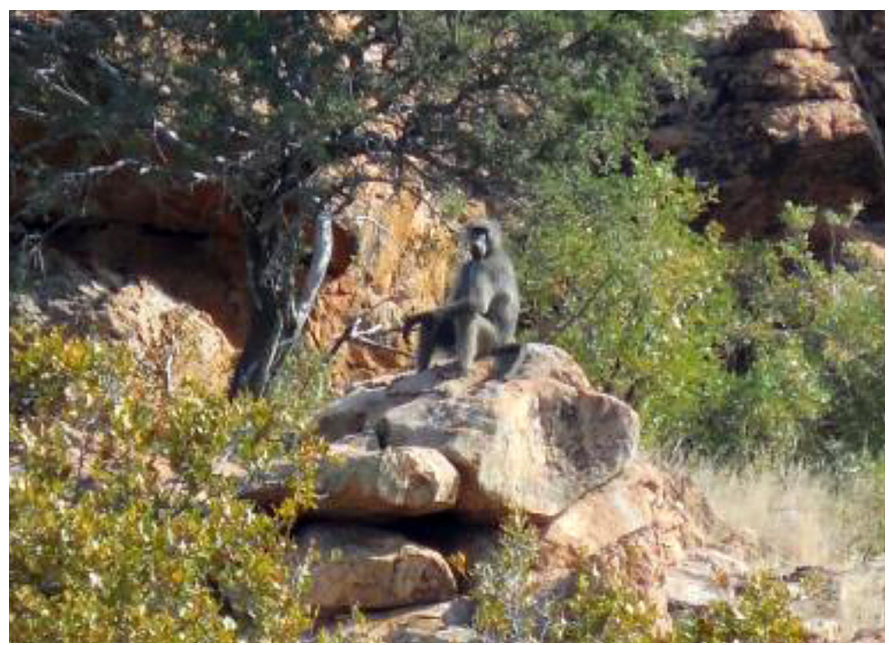

Fig. 11. One of the many Yellow Baboons (Papio cynocephalus) seen at Fly Camp. Moving in noisy troops, these social animals can be quite aggressive. Photograph by Kaitlin Danis.

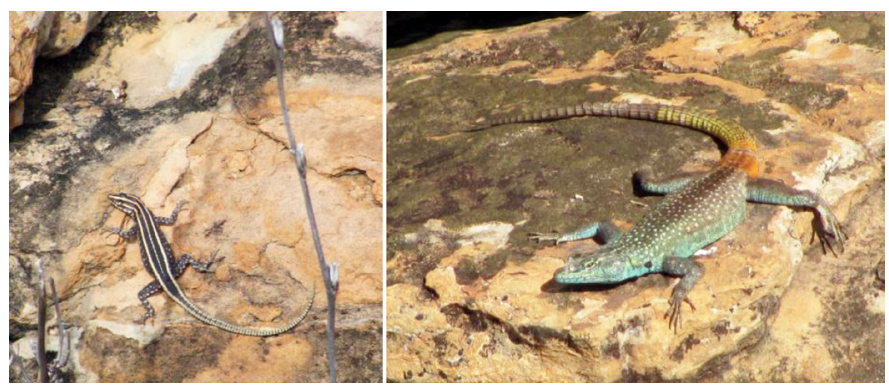

Fig. 12. Flat lizards are members of the unique African family Cordylidae. The female Sekukhune Flat Lizard (Platysaurus orientalis, left) is much less colorful than the male (right). Photographs by Gad Perry. 
close wildlife sightings, Fly Camp also provided a breathtaking view of the African plains and opportunities to see plenty of other animals, such as Yellow Baboons (Papio cynocephalus; Fig 11). Fly Camp's intricate rock outcroppings provide prime habitat for a variety of herps. Within minutes of settling in, a pair of Sekukhune Flat Lizards (Platysaurus orientalis, Fig. 12) came out to bask in the sun. Later, several skinks (genus Trachylepis) joined the action (Fig. 13). Although
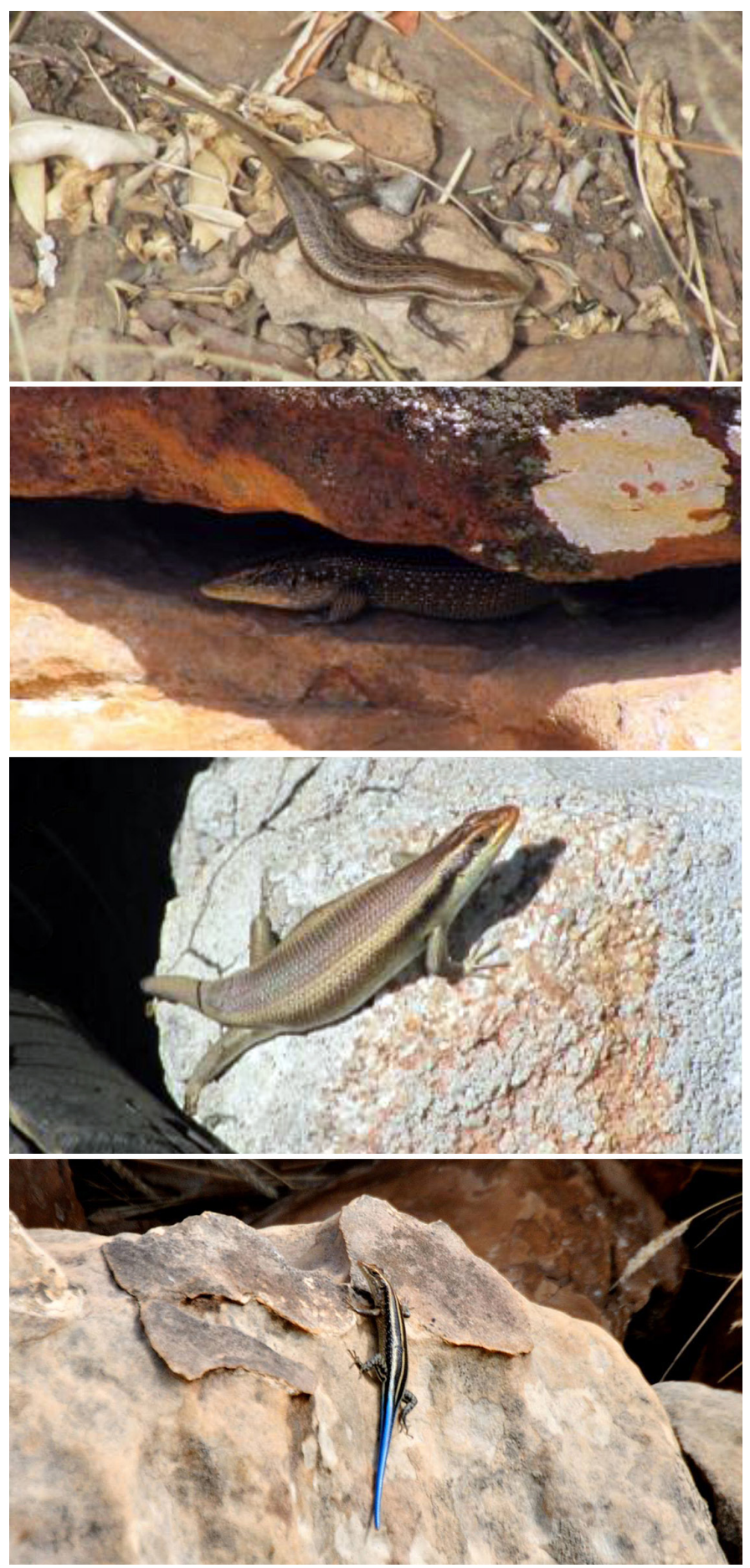

Fig. 13. Skinks of the genus Trachylepis (formerly assigned to the genus Mabuya) were seen in many settings, some of them very close to human habitation. Photographs by Gad Perry. our snake encounters on this trip were rather limited, two occurred here. First, we saw multiple tracks of what our local guides confirmed were from Mozambique Spitting Cobras (Naja mossambica). Although we never saw the snakes, we did encounter a small viperid, most likely a Horned Adder (Bitis caudalis, Fig. 14).

One afternoon while driving through the communal lands of Limpopo, we spotted a pride of African Lions (Panthera leo; Fig. 15). Sadly, one of the cats had been trapped in a snare, although we were unaware of that at the time. The whole pride was still there when we drove back that evening, triggering alarm. Help eventually arrived, but not fast enough to save the lion. While snaring wildlife is illegal, the instance

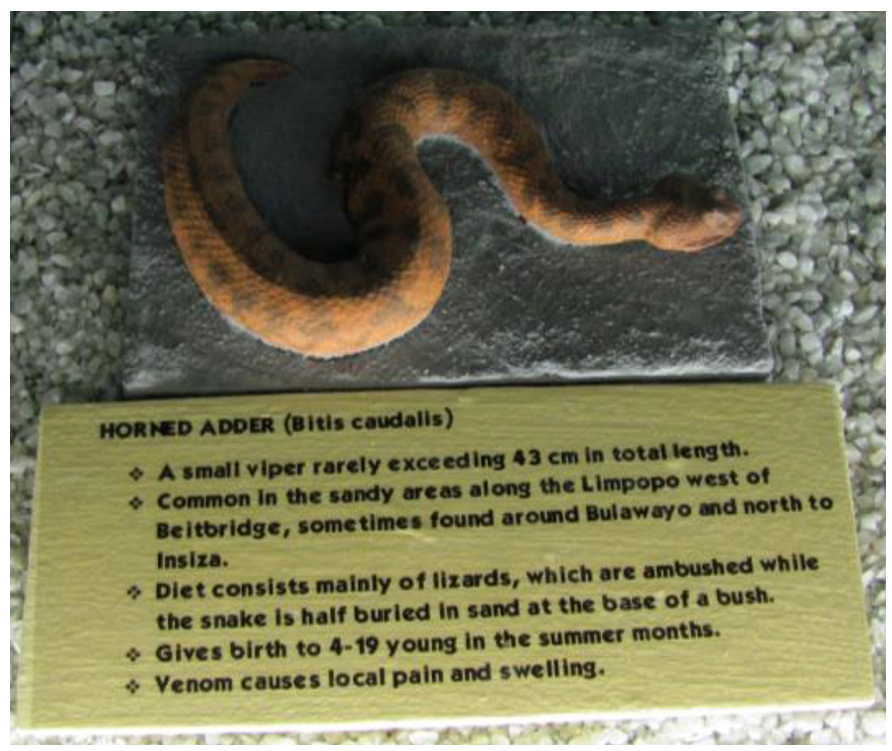

Fig. 14. A display at the Natural History Museum of Zimbabwe in Bulawayo shows a Horned Adder (Bitis caudalis). Against the reddish soil common in the region, this snake can be very hard to see. Photograph by Gad Perry.

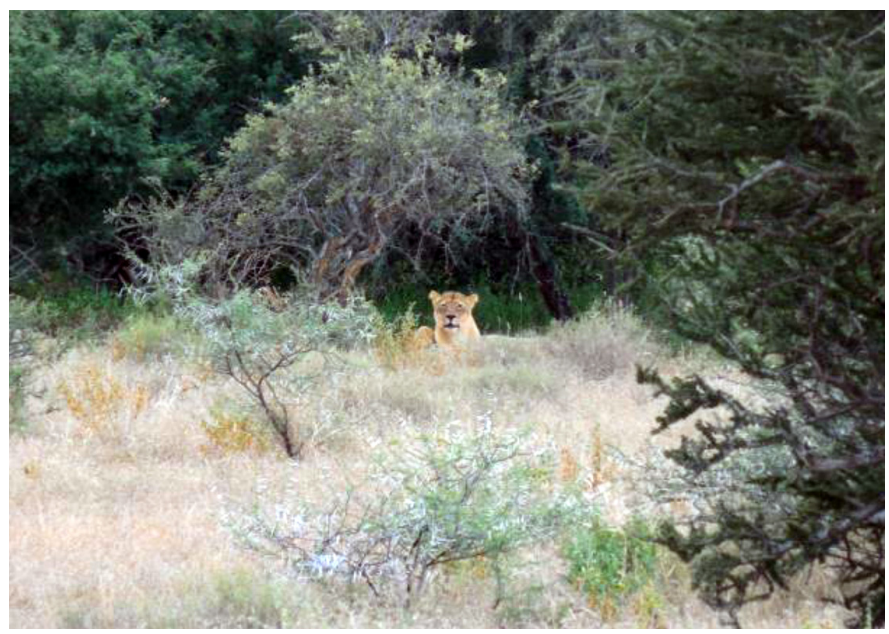

Fig. 15. A lioness spotted in the communal lands in Limpopo; one of a small pride that was likely moving through the area. Because of human persecution, few African Lions (Panthera leo) remain in Zimbabwe. Photograph by Kaitlin Danis. 
we observed exemplified the tension between conservation and economic development. Although the presence of lions encourages tourism and brings in desperately needed funds, the immediate needs of the locals to feed their families or sell a hide for money prevail over conservation of these majestic cats. The conservation successes in Africa, including Zimbabwe, have relied on finding solutions that benefit the community.

On another excursion, our guide spotted a Southern African Python (Python natalensis; Fig. 16) winding its way up a tree. Formerly known as the Rock Python, this is the largest snake in southern Africa, reaching lengths to $6 \mathrm{~m}(20$ $\mathrm{ft})$. Upon closer inspection, the snake proved to be a female basking in the midday sun. We were fortunate to spot the majestic creature, despite her impressive camouflage.

\section{Matobo Hills, Zimbabwe: The Farmhouse Matopos (http://www.farmhousematopos.com/)}

Our next few days were spent just outside Matobo National Park. Located thirty minutes from Bulawayo, the lodge is nestled near one of the enormous granite structures of the park (Fig. 17). A UNESCO World Heritage Site, the Matobo

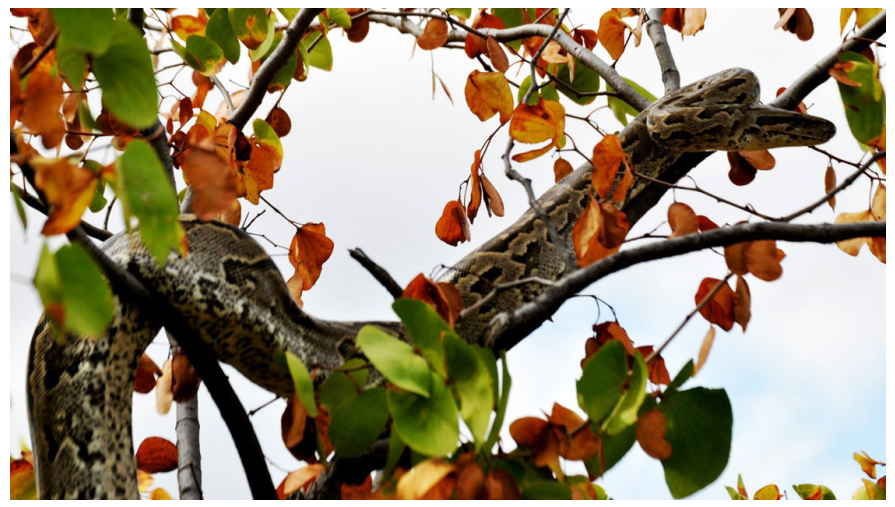

Fig. 16. This large Southern African Python (Python natalensis) was encountered while on safari. We watched it slither up the tree, but it was too fierce for our guide to try and capture. Photograph by Eric Fernandes.

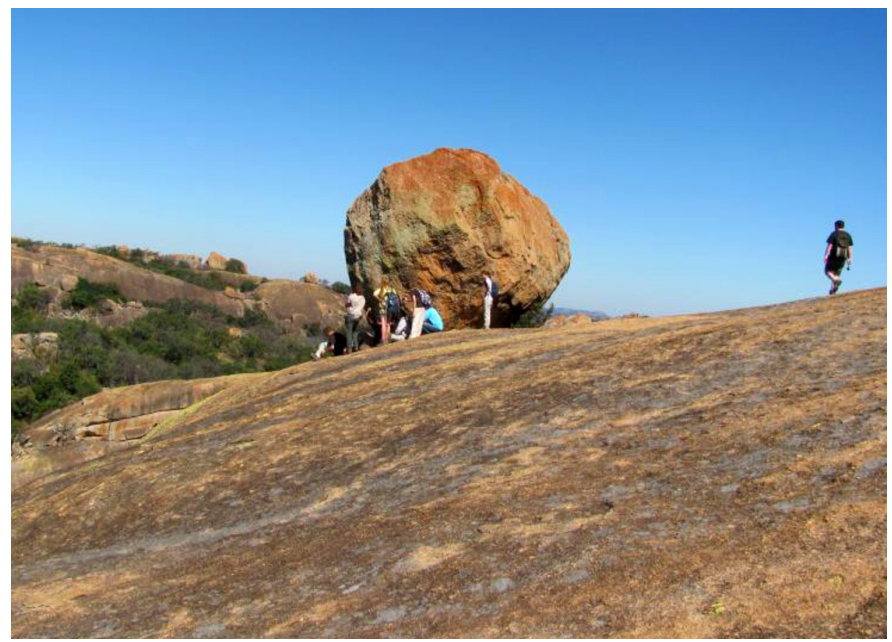

Fig. 17. Matobo National Park is world-famous for its beautiful rock outcroppings and wild landscapes. Photograph by Gad Perry.

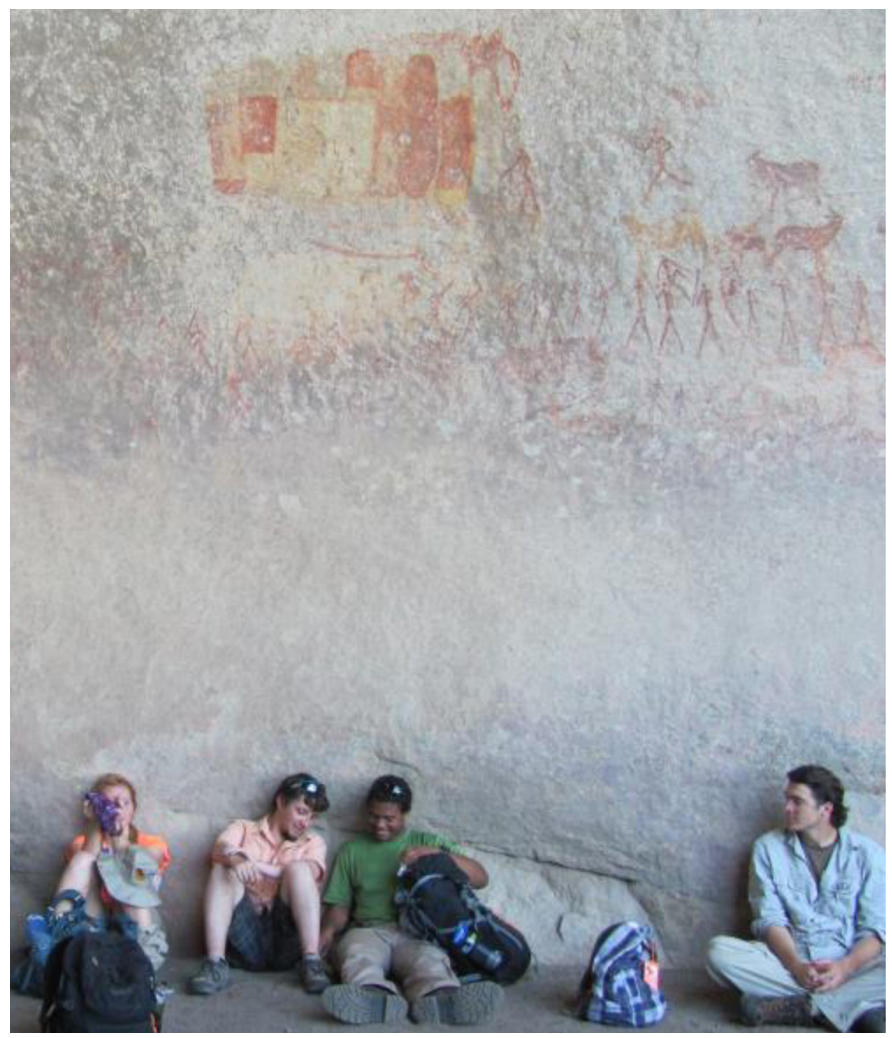

Fig. 18. Resting in a cave, the class admires rock art. Spanning hundreds of years and several cultures, these and other artifacts can tell us a lot about the humans and animals that lived in the region before Europeans arrived. Photograph by Gad Perry.

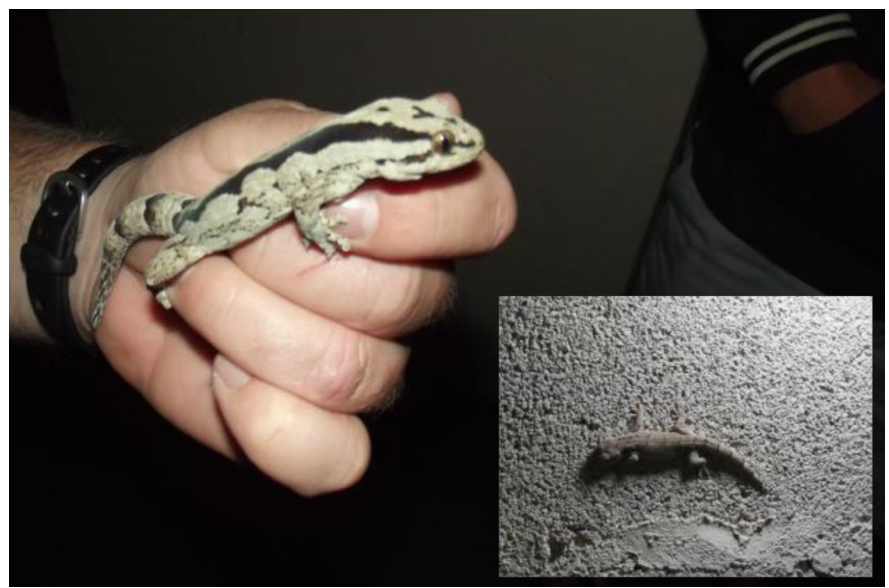

Fig. 19. An Arnold's Velvet Gecko (Homopholis arnoldi) found at a nightlight (inset) at the camp. This taxon was only recently resurrected and recognized as a species distinct from $H$. wahlbergii. Photographs by Gad Perry.

Hills are revered by anthropologists and archaeologists for their extensive variety of rock art (Fig. 18). While in Matobo, we saw a number of geckos, many of them around nightlights. The first of these was a large Arnold's Velvet Gecko (Homopholis arnoldi; Fig. 19).

Wildlife is abundant throughout Matobo National Park, which is known to have one of the largest Leopard 
(Panthera pardus) populations in Africa. Upon our arrival at the Farmhouse, we were informed that a leopard had been sighted on the property, and on several occasions, we were fortunate to view the nocturnal and well-camouflaged preda-

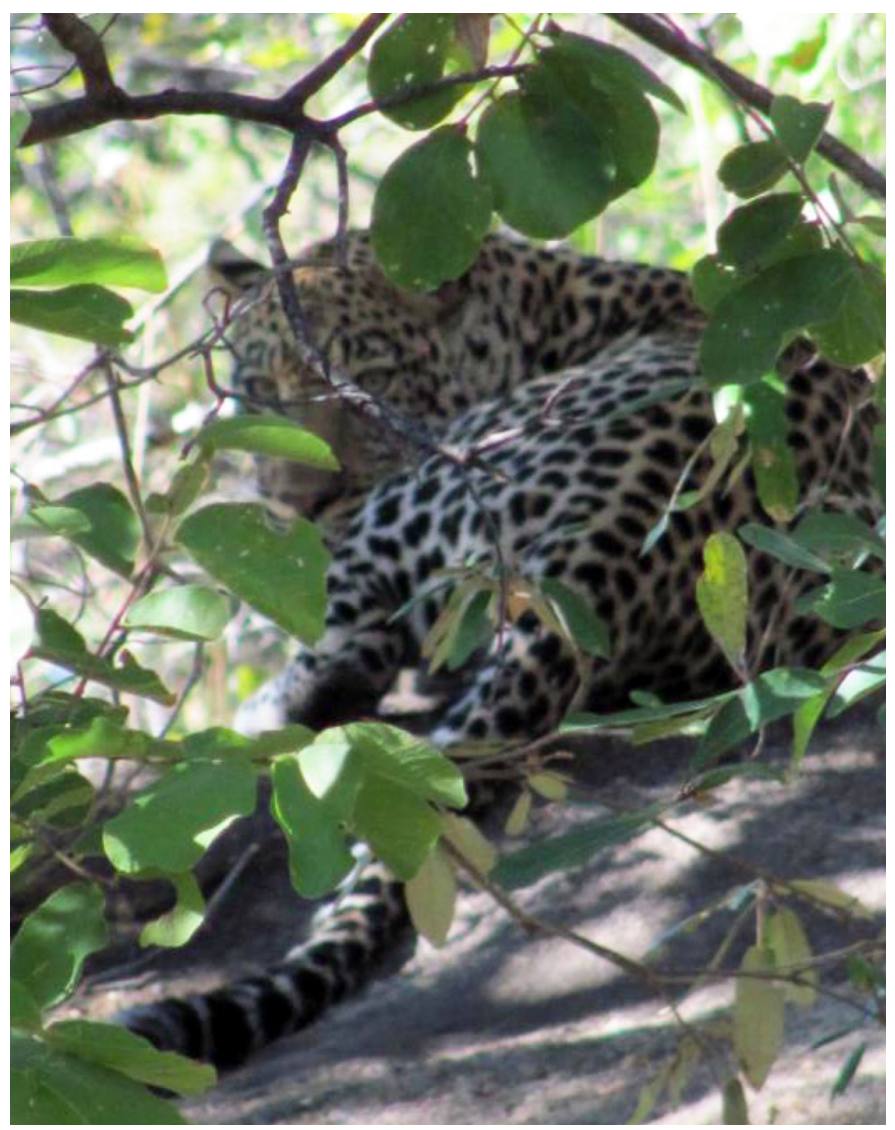

Fig. 20. This Leopard (Panthera pardus) ate one of the ostriches at The Farmhouse and hung around for several days. Leopards do not normally stay this close to human habitation for long. Photograph by Gad Perry.

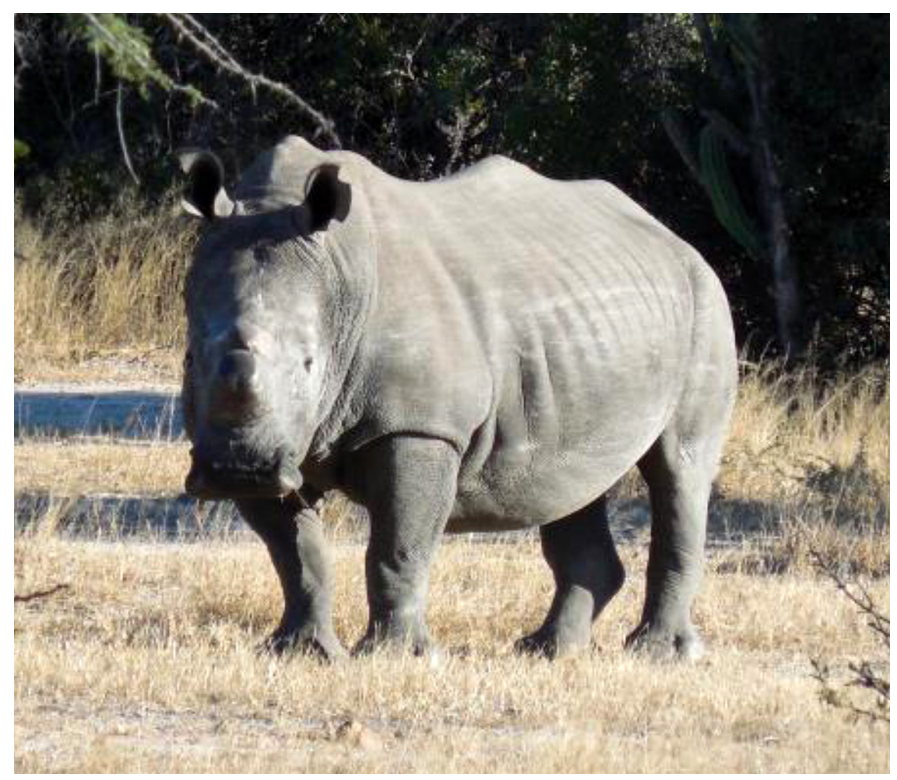

Fig. 21. Male White Rhinoceros (Ceratotherium simum) spotted on our rhino walk in Matopos. Armed guards protect the rhinos from poachers. Photograph by Kaitlin Danis. tor at a distance of a mere $16 \mathrm{~m}$ (50 ft; Fig. 20). The park also supports the highest concentrations of both Black (Diceros bicornis) and White Rhinoceros (Ceratotherium simum; Fig. 21) in Zimbabwe. Sadly, both species are declining because of well-organized and funded poaching. In an effort to combat the poaching problems, Chairman John Burton, GiveTrip, and other stakeholders created the Matobo Rhino Protection Initiative in August 2012. The Whovi Game Fence Project's goal is to build a fence around the park to improve its security and better protect the Matobo rhino populations. A portion of the initiative has already been completed, but more remains to be accomplished (Rhodes Matopos National Park). The extremely high level of training required of guides such as $\mathrm{Mr}$. Burton means that lucky tourists get to walk in rhino territory, approaching them on foot - an experience none of us will soon forget. In addition to rhinoceros, the park and The Farmhouse are home for many other wildlife species such as Giraffes (Giraffa camelopardalis; Fig. 22), Greater Kudu (Tragelaphus strepsiceros), Blue Wildebeest (Connochaetes taurinus), and Plains Zebra (Equus quagga).

While in Matobo, we visited another UNESCO World Heritage Site, the Khami Ruins National Monument (Figs. $23 \& 24$ ). Located $22 \mathrm{~km}$ (roughly $13.5 \mathrm{mi}$ ) from Bulawayo,

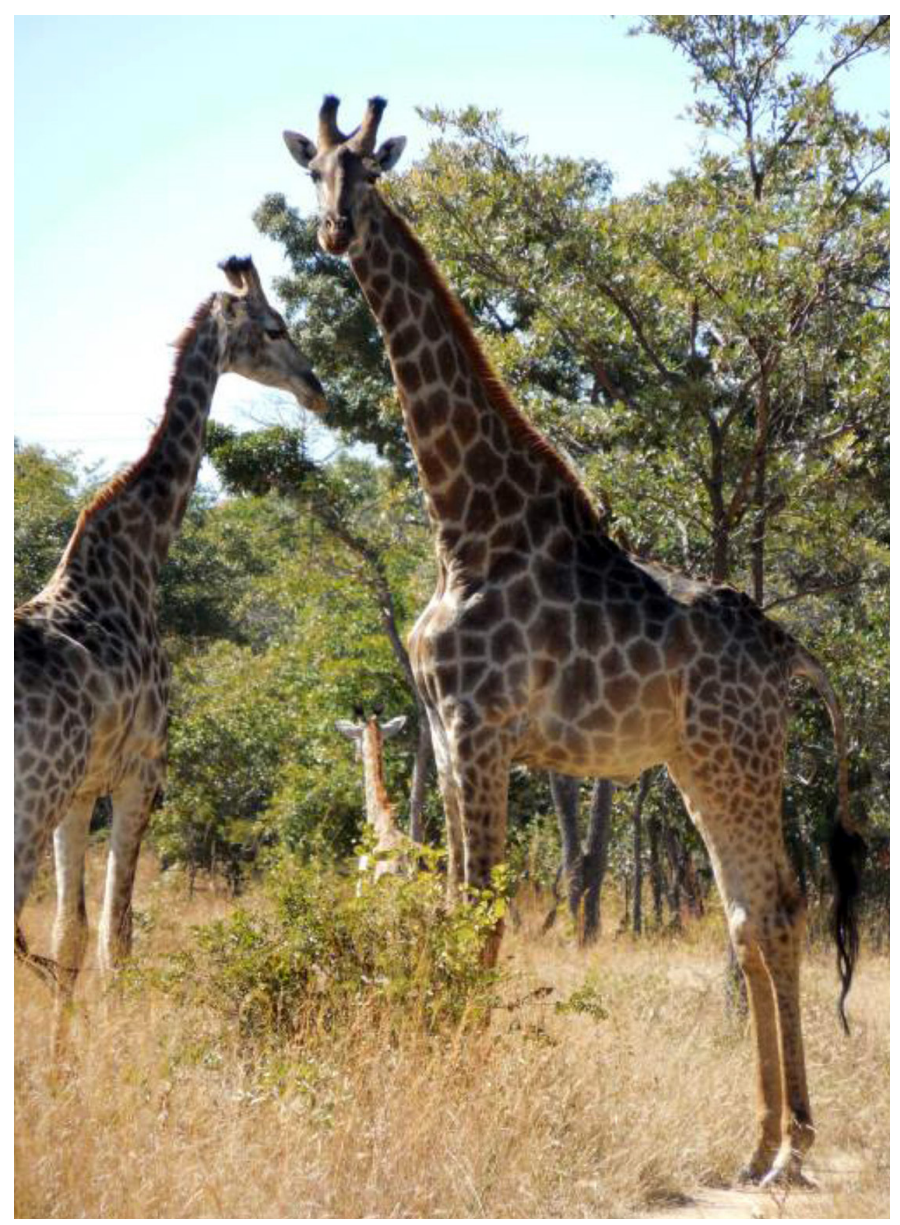

Fig. 22. A Giraffe (Giraffa camelopardalis) family observed at The Farmhouse near Matobo National Park. Photograph by Kaitlin Danis. 


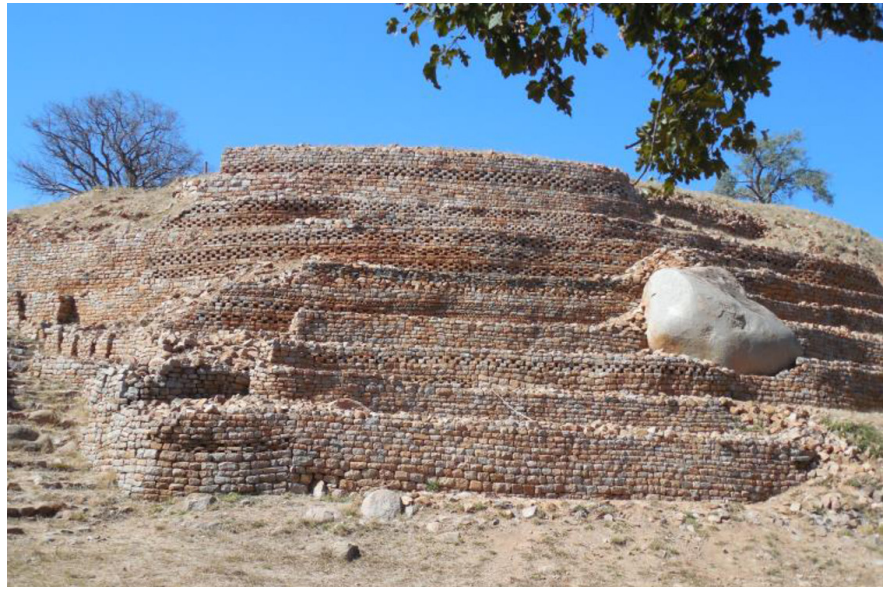

Fig. 23. Part of the Khami Ruins, a terraced walled city that served ancient rulers near modern Bulawayo, Zimbabwe. Photograph by Kaitlin Danis.

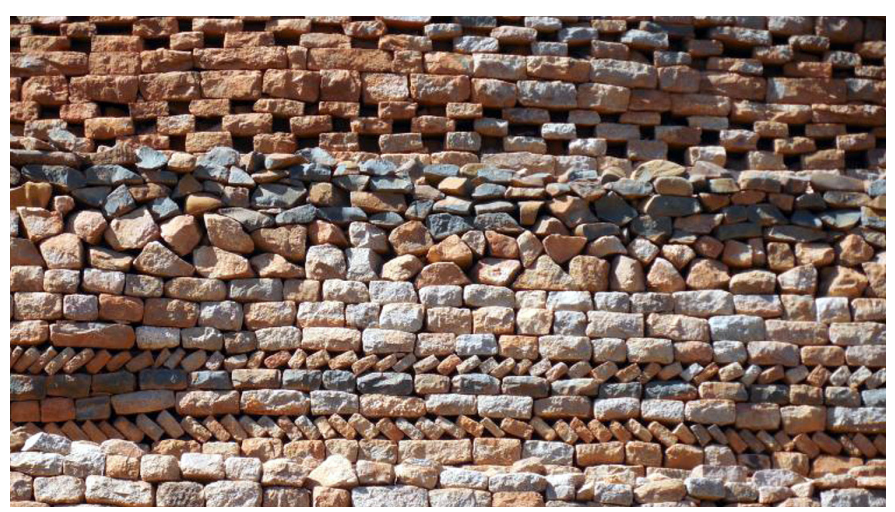

Fig. 24. A close-up view of some of the intricate stonework at the Khami Ruins. Photograph by Kaitlin Danis.

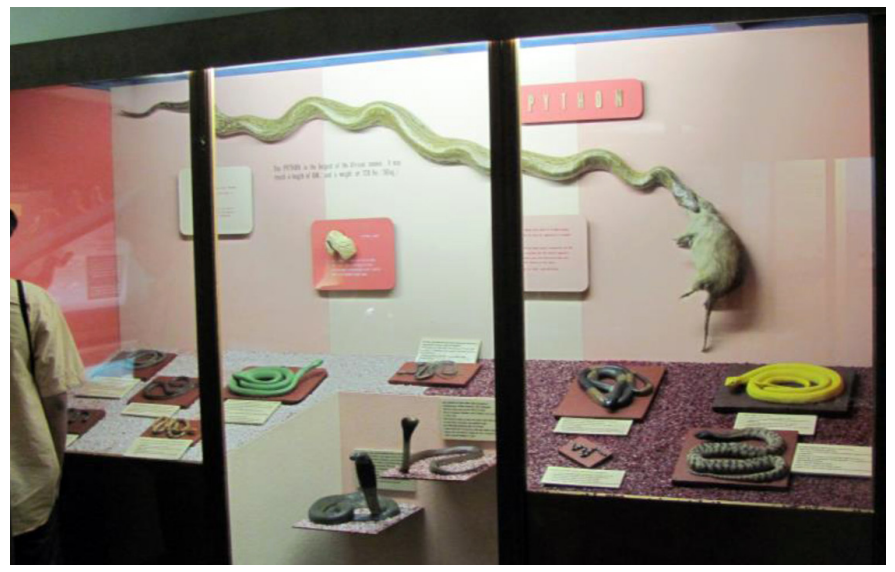

Fig. 25. One of the displays in the Broadley Gallery at the Natural History Museum in Bulawayo. Photograph by Gad Perry.

the ruins of Khami are believed to have been built during the 15th Century. One of the oldest walled cities in Africa, it is the second largest stone building monument in Zimbabwe. The size of the site and the attention to detail were indicative of a much more sophisticated culture at that time than any of us had suspected. We recommend stopping by the Bulawayo
Natural History Museum. In addition to an extensive exhibit featuring the cultural history of the Khami Ruins, it also provides a look into the history of the city and the Ndebele culture. A section also is devoted to local reptiles and amphibians (Fig. 25), and the museum is home to Dr. Don Broadley, one of the foremost experts on African herpetology. Although old-fashioned, the displays show many of the more noteworthy local species, including some live snakes that are used in periodic public-education efforts.

\section{Hwange, Zimbabwe: Camelthorn Lodge (http://www.imvelosafarilodges.com/ camelthorn-lodge.html)}

Hwange National Park was the final educational stop on our tour. This park has recently been in international news because Cecil the Lion was killed just outside its boundaries. Mark Butcher, Imvelo Safari Lodges' co-owner, was waiting to welcome us to Camelthorn Lodge just outside the park's gates (Fig. 26). Hwange National Park is the largest reserve in Zimbabwe and has the highest wildlife population density and biodiversity of all of the places that we visited. In the

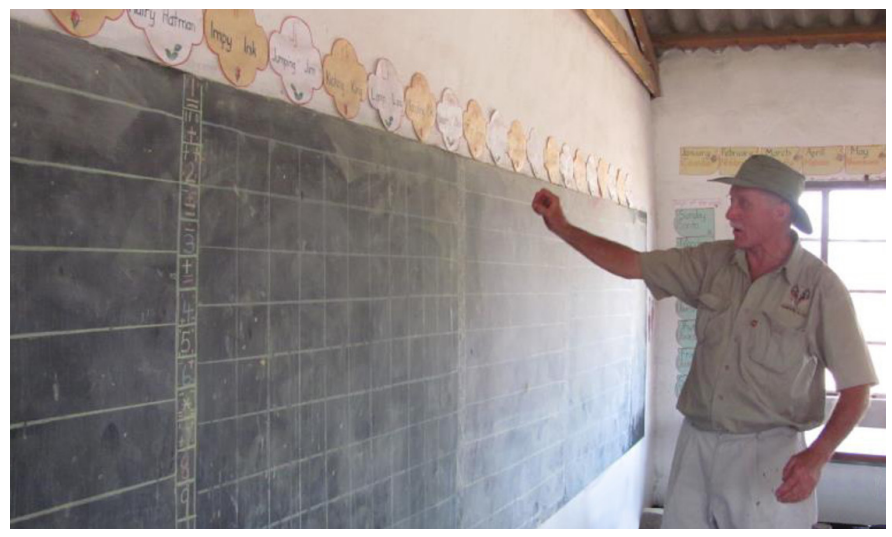

Fig. 26. Mark Butcher, whose tourism ventures at Hwange National Park help support this school and provide other benefits to the community. Photograph by Gad Perry.

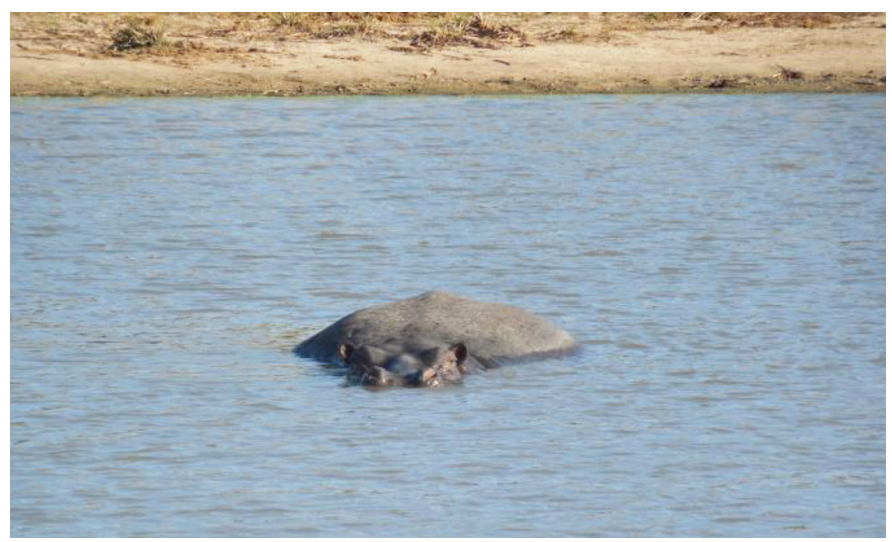

Fig. 27. A Common Hippopotamus (Hippopotamus amphibious) in a temporary pond at Hwange National Park. Hippos can be quite dangerous. They feed at night on land, where they can move surprisingly fast. Photograph by Kaitlin Danis. 
five days we spent in Hwange, we saw the gamut of African species, including Common Hippopotamus (Hippopotamus amphibious; Fig. 27), African Buffalo (Syncerus caffer), Grey Hornbill (Tockus nasutus), Black-backed Jackal (Canis mesomelas), the snake-eating Secretary Bird (Sagittarius serpentarius, Fig. 28), Black-faced Impala (Aepyceros melampus), and zebra. Cheetahs (Acinonyx jubatus) also occur in the area, but we saw none during our trip.

Easiest of the species to find is the icon of Hwange National Park, the African Elephant (Loxodonta africana; Fig. 29). A staggering 40,000 of them inhabit the $14,651-\mathrm{km}^{2}$ park $(5,700 \mathrm{sq} \mathrm{mi})$, exceeding the carrying capacity by some 25,000 . In the early 1930 's, one of the park staff began building water pumps in Hwange with hopes of increasing the wildlife population. By then, development in surrounding areas had prevented the traditional migration of elephants away from the park, which lacks permanent water sources during the dry season. With the addition of the pumps, the elephant popula-

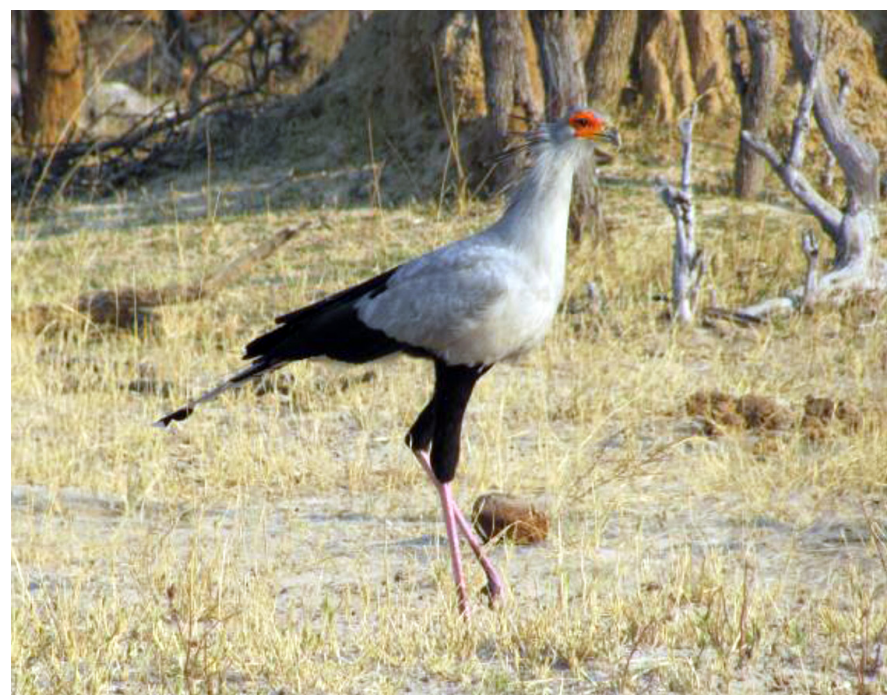

Fig. 28. The Secretary Bird (Sagittarius serpentarius) spends most of its time walking in the grass savannah. It can feed on even the most venomous of snakes. Photograph by Gad Perry.

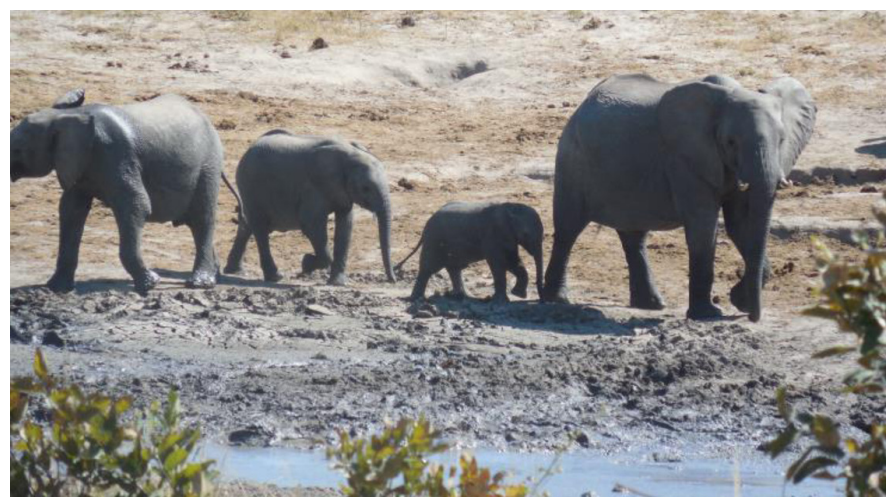

Fig. 29. A family of African Elephants (Loxodonta africana) slinging mud on themselves as a way to keep cool. The large number of elephants at Hwange has resulted in a loss of vegetation in large areas of the park. Photograph by Kaitlin Danis. tion skyrocketed, detrimentally impacting the flora and other fauna. The plant life, including the Acacia Trees, is severely overgrazed, and the land surrounding water holes caves inward beneath the immense weight of the elephant herds. Other species are unable to access the limited water sources when elephants are present, and eventually disappear as they are unable to compete. The smaller species are not the only ones suffering, however; whenever periodic droughts occur, elephants die in large numbers. Sometimes, the elephants cross the park's border fences and consume entire fields of crops grown by local residents. This directly increases the locals' propensity to poach and disregard the elephants' role as a primary source of tourism and indirect source of income.

We discussed several methods that could help restore Hwange to its natural carrying capacity. However, none of them seem to be socially acceptable, physically possible, or economically feasible. Culling the elephants is unacceptable to a western society that believes elephants are endangered (as many populations are). Removing the water sources will lead to the slow and horrendous death of many animals. Local budgets for park maintenance are minimal, and trade in ivory, which could fund much management, is banned by international treaty (CITES, the Convention on the International Trade in Endangered Species). Finally, the option of relocating elephants would require an elephant-free area as large and rich in biodiversity as Hwange, which is simply not available. This leaves Zimbabwe with tourism and agriculture as its two primary legs for development, and few options for managing the over-populated elephant herd.

As part of our service learning, we helped start some of the water pumps that Camelthorn maintains on behalf of the Park Service. The pumps are turned off during the wetter months and are on only when other sources of water dry up. The water is collected in troughs, and within minutes of its arrival in the dusty concrete reservoirs, small frogs (Fig. 30) emerged from the cracked soil at the bottom of the water tank.

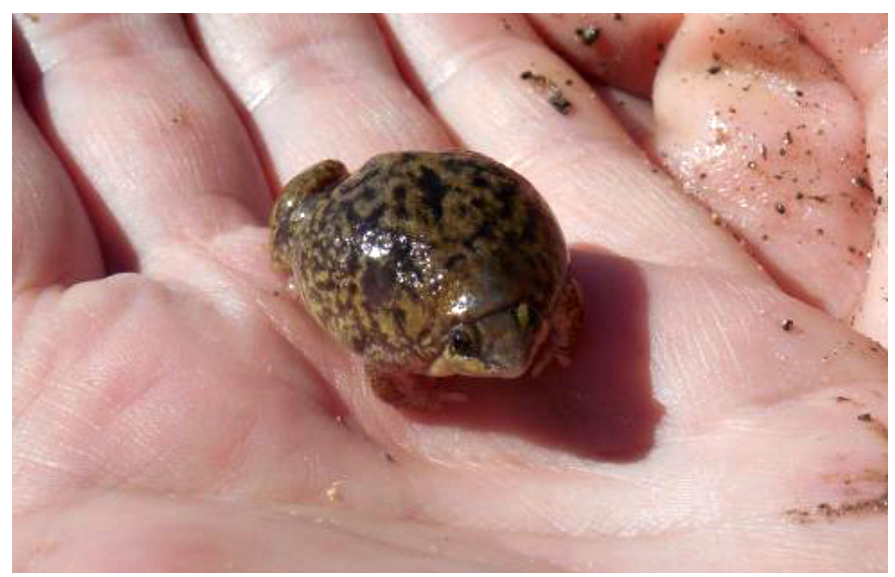

Fig. 30. The Mottled Shovel-nosed Frog (Hemisus marmoratus) spends much of its life underground and emerges when rain wets the soil. Photograph by Kaitlin Danis. 
We encountered Dwarf Geckos (genus Lygodactylus) in many places during our trip, usually near human habitation. Unlike most geckos, these small lizards are diurnally active, and like the day geckos of Madagascar and South America, they have round pupils. The only one we encountered in natural habitat (Fig. 31) was seen during a safari drive in the course of our our stay in Hwange. We also encountered lizards of two other families in the Hwange area. We briefly saw a plated lizard (Gerrhosauridae; Fig. 32) during a hike, but it quickly retreated into a hole in a stump and was never seen again. More common were lizards in the family Agamidae, which we saw on rocky outcroppings in some of the towns near the park (Fig. 33).

For the better half of a day in Hwange, Mr. Butcher instructed a small group of us on proper tracking techniques. Using animal tracks, wind direction, and a variety of other clues, we followed and successfully located a herd of African Buffalo. Tracking is an essential tool when working in wildlife biology, so this was an invaluable opportunity to learn this technique from an esteemed wildlife guide.

Another experience provided by Imvelo Lodges for their guests is the opportunity to visit the communal lands found nearby. We spent half a day interacting with the Ndebele people, learning how the men herd cattle and plow crops while the women gather firewood and prepare food. Additionally,

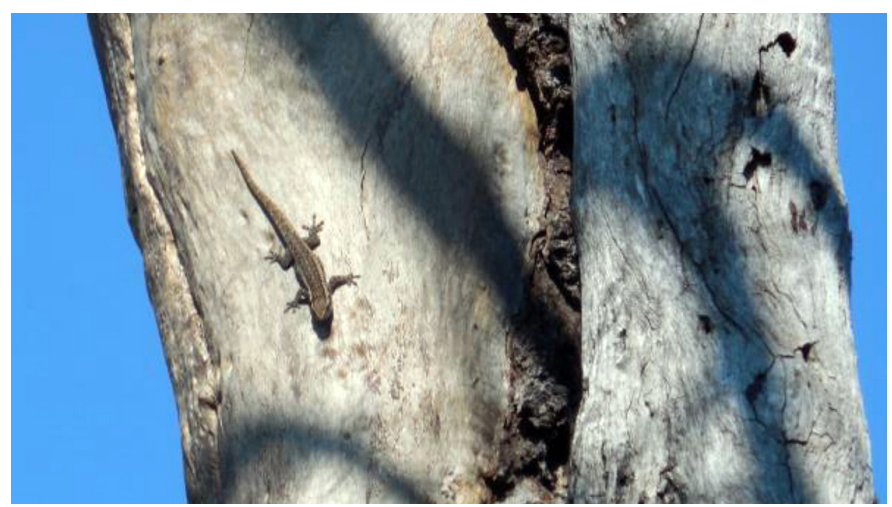

Fig. 31. Diurnally active Dwarf Geckos (genus Lygodactylus) have round pupils and are commonly encountered on houses, fence-posts, and trees in Zimbabwe. This individual was encountered during a safari drive at Hwange National Park. Photograph by Gad Perry.

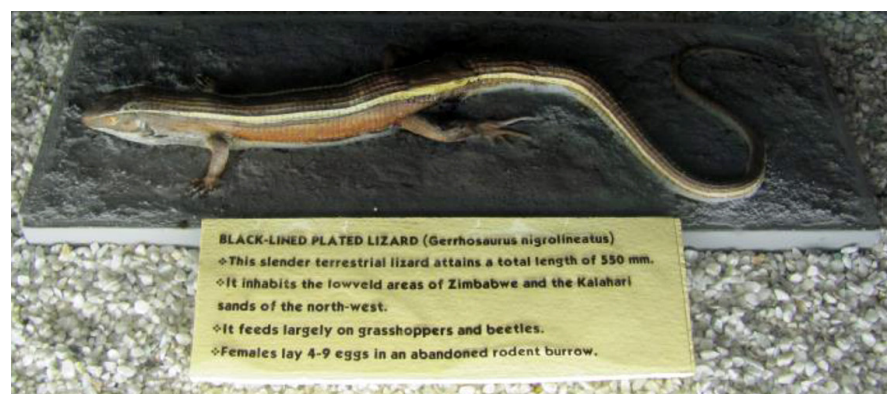

Fig. 32. Plated Lizards are assigned to the uniquely African family Gerrhosauridae. This model is at the Natural History Museum in Bulawayo. Photograph by Gad Perry.

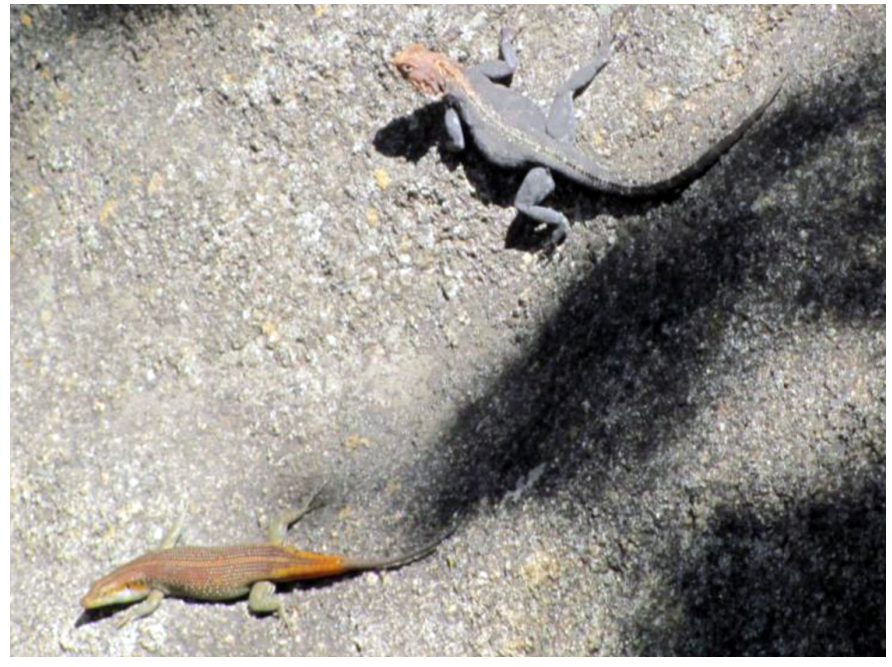

Fig. 33. A male agama (family Agamidae) and a skink (probably genus Trachylepis) with a regenerating tail share a sunny rock in a town near Hwange National Park. Photograph by Gad Perry.
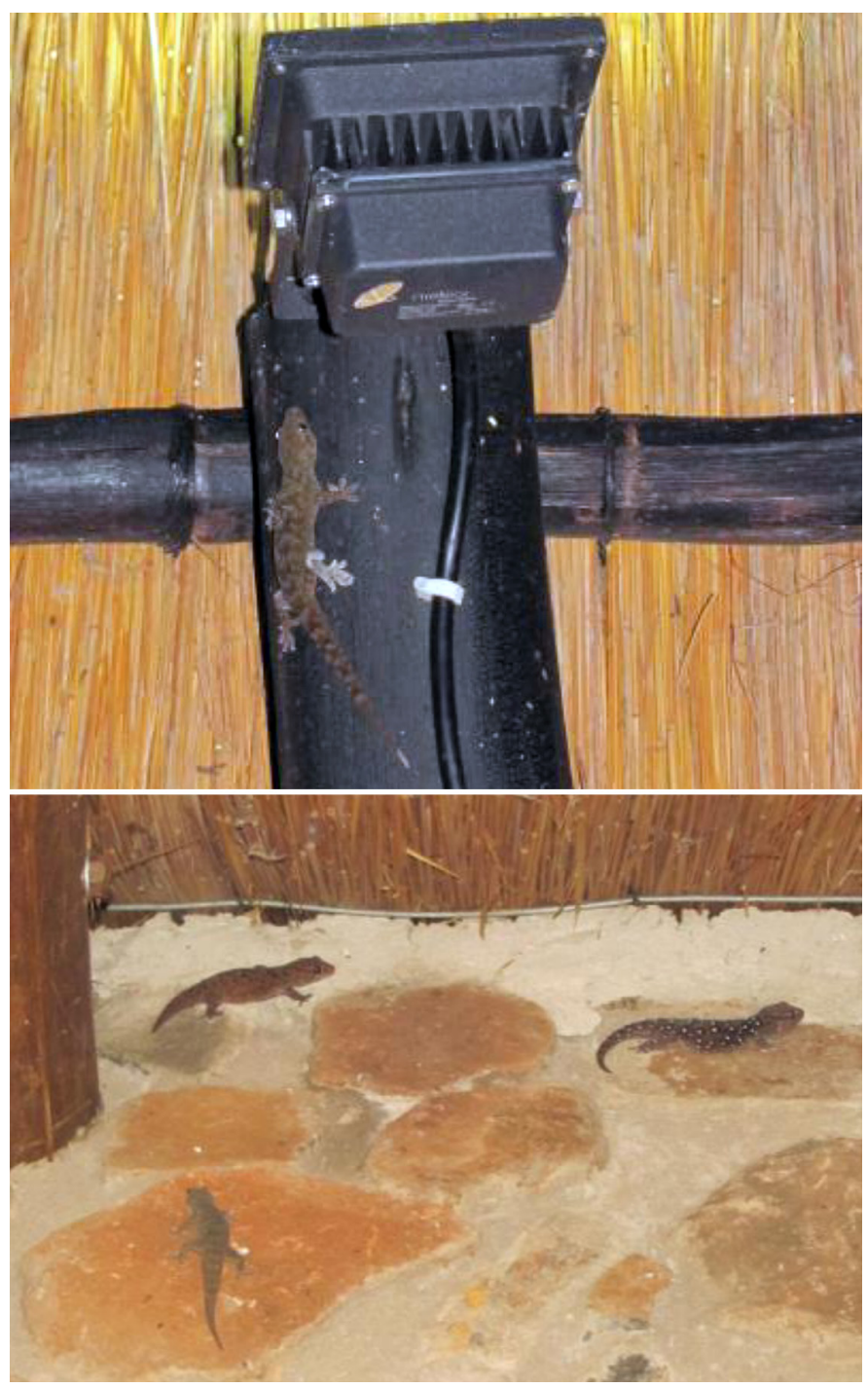

Fig. 34. Night-lights at the Gorges Lodge offer hunting opportunities for several species of geckos, sometimes at high densities. Photographs by Gad Perry. 
we were invited to the local school where our group was divided among the three subjects being taught (science, math, and English) and sat in on their classes. Exchanging stories and ideas with the students was a valuable learning experience for us all. After classes concluded, we spent the afternoon teaching them some our favorite American pastimes, including playing catch with a Frisbee and playing tee-ball. In return, they trounced us at soccer.

\section{Victoria Falls, Zimbabwe: Gorges Lodge}

(http://www.imvelosafarilodges.com/gorges-lodge.html)

We concluded our trip with two days at Gorges Lodge by Victoria Falls in the northwestern tip of Zimbabwe. One of the seven natural wonders of the world and the third UNESCO World Heritage Site visited during this trip, Victoria Falls, which forms the border between Zambia and Zimbabwe (Zambia Tourism 2015), stretches nearly 1,700 m (approximately 5,500 ft) in width and $108 \mathrm{~m}$ (approximately $350 \mathrm{ft}$ ) in height. Known as Mosi-oa-Tunya, "The Smoke that Thunders," Victoria Falls is a popular tourist attraction, bringing in visitors from all over the world.

The streets around the falls are lined with vendors and their shops, stocked with hand-carved wooden animals, jewelry, and rain ponchos. However, one of the hottest tourism items are the demonetized Zimbabwean dollar bills, including the 100 trillion-dollar bill, sold by men wandering the streets with the hope of making a few US dollars. Although the bill's bright colors and high values make them an excellent souve- nir, they also provide a glimpse into Zimbabwe's turbulent economic past. Zimbabwe now uses the US dollar as its official currency, and tourists are advised to bring lots of one- and five-dollar bills, as change from higher denominations may be difficult to obtain.

Located about a thirty-minute drive from the falls, Gorges Lodge is nestled right up against the Zimbabwean side of the Bakota Gorge, which overlooks the mighty Zambezi River. This was the perfect location to relax and unwind after three very busy, fulfilling, and educational weeks. In addition to the incredible scenery, we got to see the final additions to our herpetological checklist; several species of geckos that took advantage of the night-light niche made available by the resort (Fig. 34).

Prior to beginning this trip, everyone told us that studying abroad would change our lives forever. Leaving Zimbabwe, we clearly were not the same Texas Tech students who had arrived three weeks earlier. Although the immediate changes were not obvious to everyone, we can now look back and recognize just how much this trip and the beautiful country of Zimbabwe impacted our lives (Fig. 35).

\section{Acknowledgments}

We thank our professors, Drs. Tamra Walter, Michael Farmer, and Gad Perry. For logistical arrangements, we are indebted to Debby Gracy, Brent Holbert, and Alistair Burton from GiveTrip (www.givetrip.org), and the owners and staff of all of the locations we visited.

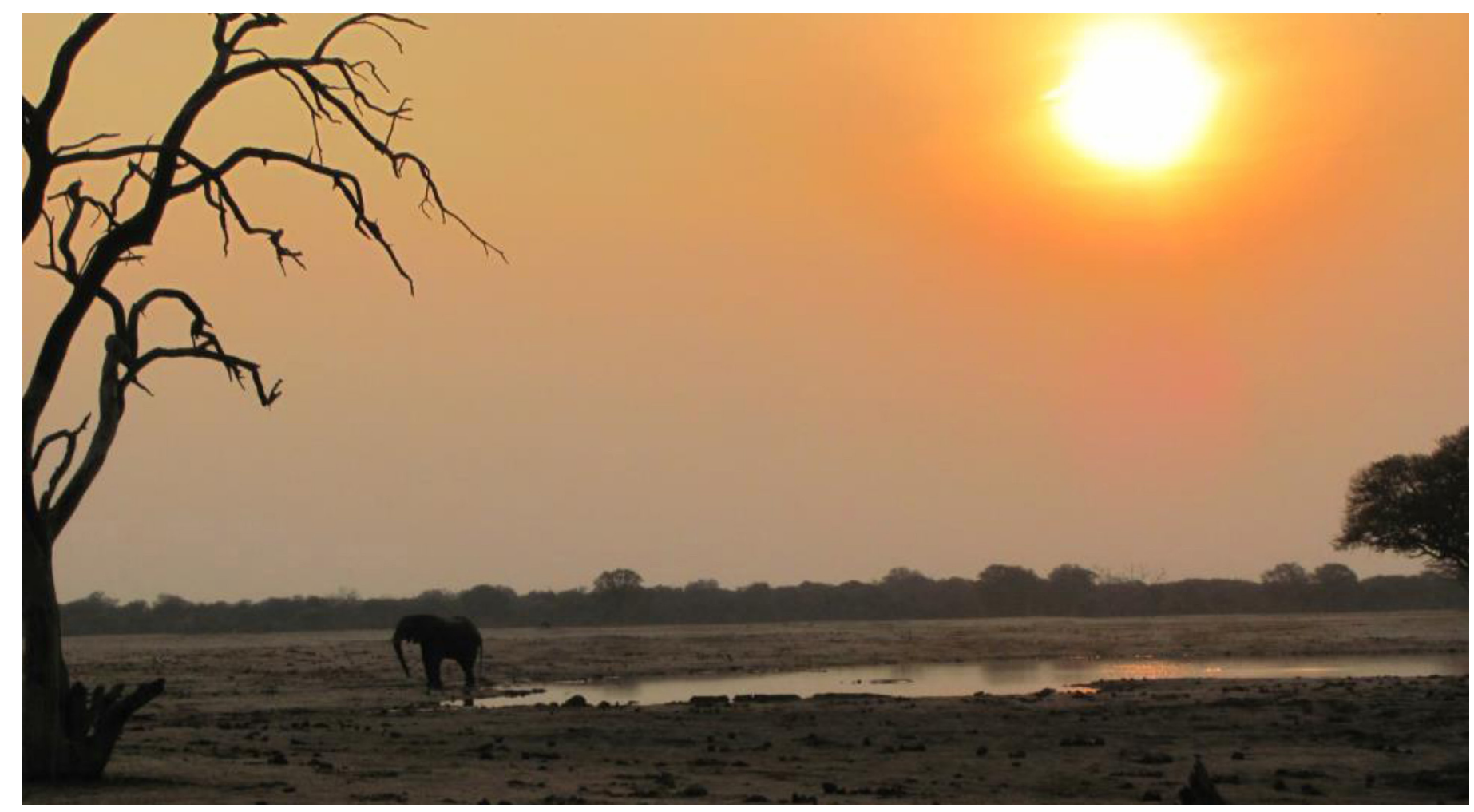

Fig. 35. This elephant, one of dozens we encountered at Hwange National Park, posed for a sunset photograph near one of the seasonal water holes. This was a great way to end the day, and a great image with which to remember Zimbabwe. Photographs by Gad Perry. 


\section{References}

Alexander, G. and J. Marais. 2007. A Guide to the Reptiles of Southern Africa. Struik Nature, Cape Town, South Africa.

Du Preez, L. and V. Carruthers. 2009. A Complete Guide to the Frogs of Southern Africa. Struik Nature, Cape Town, South Africa.

Lambiris, A.J.L. 1989. The Frogs of Zimbabwe. Museo Regionale di Scienze Naturali, Torino, Italy.

Marais, J. 2004. A Complete Guide to the Snakes of Southern Africa. 2nd ed. Struik Nature, Cape Town, South Africa.

\section{Websites}

Khami Ruins National Monument. <http://whc.unesco.org/en/list/365>.

National Geographic. Nile Crocodiles, Nile Crocodile Pictures, Nile Crocodile Facts. $<$ http://animals.nationalgeographic.com/animals/reptiles/nile-crocodile/>.

Rhodes Matopos National Park. <http://www.rhodesmatopos.com/>.

Zambia Tourism. The Victoria Falls. <http://www.zambiatourism.com/destinations/ waterfalls/victoria-falls>. 